\title{
Examining Information Disclosure on Regulatory Compliance of Telecommunication Companies in Nigeria
}

\author{
Sini Fave Kwaji and Ishaya John Dabari \\ Department of Accountancy, School of Management and Information Technology Modibbo Adama \\ University of Technology, Yola, Adamawa State- Nigeria
}

\begin{abstract}
This study examined the impact of information disclosure on regulatory compliance of telecommunication companies in Nigeria. The study adopted ex-post facto research design which relied on secondary data collected from the financial statements of three (3) telecommunication companies out of the eight (8) telecommunication companies for the period of 2004 to 2015 . The multiple regression statistics were used to analyse the data. The results indicated that computed compliance index of telecommunication companies was partially complied (av. $75.6 \%$ ) with the requirements of regulatory agencies. Furthermore, the findings revealed that mandatory information disclosure (MID) has a significant impact at 10\%, this shows weak compliance by the telecommunication companies, while voluntary information disclosure (VID) has a significant impact at $5 \%$. This means that there is partial compliance by the telecommunication companies. Thus, this study made a clarion call for the enforcement of full compliance by all the telecommunication companies operating in Nigeria. It is, therefore, recommended that National Communication Commission (NCC) should monitor the compliance with the requirements of information disclosure and pursue its objective to achieve best corporate governance practices in Nigerian telecommunication companies.
\end{abstract}

Keywords: Regulatory compliance, Information disclosure, Telecommunication, Nigeria

JEL Classification Code: M40, M41, M49

Paper Type: Research

\section{INTRODUCTION}

Regulatory compliance is the regulations a company must follow the specific requirements. However, the international capital arena has been found to comply with disclosing mandatory requirements and also disclose significantly more voluntary accounting information that enables them to compete globally (Meek, Roberts \& Gray, 1995). Mandatory information disclosure provides users of the annual report with a factual

* Corresponding author: E-mail: sinifavek@gmail.com, Phone: +2347036920159 
account of the organisation's compliance with regulations during the period of reporting (Cowan \& Gadenne, 2005). Voluntary disclosure in the annual reports and other information media has been one of the rapidly growing research areas in the accounting field. Several factors have played essential roles in voluntary disclosure. Among them are the development of communication tools, stakeholders' need for more transparency, accountability, and corporate governance practices (Bleck \& Liu, 2007).

Telecommunication companies in Nigeria are expected to comply with disclosure requirements stipulated by the regulatory agencies such as the National Communication Commission (NCC) Act, 2011. Securities and Exchange Commission (SEC) Decree No. 71 of 1979 and the Corporate Affairs Commission (CAC) established by Decree1 Companies and Allied Matter Acts (CAMA) 1990. However, existing literature evidenced from the work of Akhtaruddin (2005) posits that Telecommunication companies operating in Nigeria do not mostly comply with these statutory regulations, but the researcher did not explicitly state why those companies do not comply with the regulatory requirements. This calls for further research for the identification of the factors responsible for lack of compliance with the regulations. Several studies have been conducted in Nigeria on the level of compliance with Accounting Standards and other regulatory compliance, which among others include Kantudu and Tanko (2008) and Barde (2009). However, there have inconsistent findings from the studies. This justifies the reason for this research. Therefore, this study examined the level of compliance on Telecommunication companies in Nigeria.

This study examined the impact of information disclosure on regulatory compliance of Telecommunication in Nigeria with the following specific objectives: (1) to determine the impact of Mandatory Information disclosure on the compliance of Telecommunication Companies in Nigeria; and (2) to assess the impact of Voluntary information disclosure on Compliance of Telecommunication companies in Nigeria. In line with the research objectives, the authors raised the following research questions: (1) Does Mandatory information disclosure significantly impact on Compliance of Telecommunication Companies in Nigeria?; and (2) Does Voluntary information disclosure significantly impact on Compliance of Telecommunication in Nigeria?

\subsection{Hypotheses of the Study}

Within the framework of the research objectives and research questions, the following hypotheses were developed to guide the study:

$\mathrm{H}_{1}$ Telecommunication Companies in Nigeria does not significantly comply with mandatory information disclosure.

$\mathrm{H}_{2}$ Telecommunication Companies in Nigeria does not significantly comply with Voluntary information disclosure.

\subsection{Significance of the Study}

The significance of this study covers the beneficiaries, the management of telecommunication organisations, shareholders of telecommunication business, potential investors, regulatory agencies such as National Communication Commission (NCC), Corporate Affairs Commission (CAC), researchers, academics and the general public. Regulatory agencies like National Communication Commission (NCC) and Corporate Affairs Commission (CAC), will possibly derive some level of benefits, and this, in turn, helps in the issuance of necessary compliance directives, and improve the compliance mechanisms to ensure a reasonable level of compliance by all Telecommunication Companies. Researchers and academicians will equally benefit by adding to the stock of literature on information disclosure and compliance with the law of the land. The general 
public also benefited from this research since it enhances compliance with a statutory framework which will enhance the quality of information disclosure, thereby restoring users confidence in Telecommunication Companies.

\section{LITERATURE REVIEW}

\subsection{Regulatory Compliance}

Tom (2016) stated that regulatory compliance could be taken on different definitions according to the industry in which the policies are applied since compliance means incorporating standards that conform to specific requirements. Regulatory compliance is the regulations a company must follow the specific requirements (Cohen, 1985; Kaufmann, 1997). Compliance means conforming to a rule, such as a specification, policy standard or law. Regulatory compliance describes the goal that organisations aspire to achieve in their efforts to ensure that they are aware of and take steps to comply with relevant laws, policies, and regulations due to the increasing number of regulations and the need for operational transparency. Organizations are increasingly adopting the use of consolidated and harmonised sets of compliance controls.

\subsection{Information Disclosure}

Paul (2015) stated that information disclosure means a series of behavioural regulations and activity standards for relevant parties in the securities market who publicise the information related with securities by the particular way in the process of issuing stocks. Listing on the market, and trading, according to laws, and rules of securities administrative agencies and Stock Exchanges. On the other hand, the Central Bank of Nigeria, (2009), defined full disclosure as the mandatory financial, operational and management information which financial institutions are required to disclose in the rendition of their periodic returns to the regulatory authorities and the public. In Nigeria, the disclosure of financial statement reports started with the Companies Ordinance of 1922 (as amended) and through to the Companies Act of 1968 and now the Companies and Allied Matters Act (1990 as amended). The Financial Reporting Council of Nigeria (Formerly NASB) is also involved in the efforts at evolving and promoting financial disclosure. The NASB was established in 1982 with the power to set and issuing accounting standards which have to be complied with while preparing financial statements. Nigeria has adopted the International Reporting Standards (IFRS) effective from 1st January 2012 and as well changed the name of its national Standards setting body from the Nigeria Accounting Standards Board to the Financial Reporting Council of Nigeria.

\subsection{Mandatory Information Disclosure}

Mandatory information disclosure provides users of the annual report with a factual account of the organisation's compliance with regulations during the period of reporting. (Cowan \& Gadenne, 2005). The mandatory disclosures are international standards, studies on mandatory disclosure practices in Zimbabwe was conducted by Owusu-Ansah (1998) and Chamisa (2000). Owusu-Ansah (1998) empirically investigates the degree of influence of eight corporate on the extent of mandatory disclosure and reporting companies in Zimbabwe. Owusu-Ansah (1998) and Chamisa (2000) used an unweighted relative disclosure index method which consists of 32 disclosure items from the three regulatory sources Zimbabwe. (i.e., they adopted IAS, the Companies Act, and the listing 
rules of the ZSE). To capture the intensity of the disclosure of these items, they were disaggregated into 214 sub-items.

\subsection{Voluntary Information Disclosure}

Voluntary disclosure in the annual reports and other information media has been one of the rapidly growing research areas in the accounting field. In this study, several factors have played important roles. Among them are the development of communication tools, stakeholders' need for more transparency, accountability and corporate governance practices (Bleck \& Liu, 2007). Voluntary disclosure refers to additional information delivered by firms besides the mandatory information disclosure. Voluntary disclosure is defined as the information primarily outside the financial statements that are not explicitly required by accounting rules or standards (FASB, 2001).

\subsection{Review of Empirical Studies}

The provisions of statutes of regulatory compliance are a matter of law has to be complied with including those in the financial sector. Asada (2010) traced the origin of statutes in the regulation of financial reporting in Nigeria to United Kingdom (UK) during the industrial revolution. It is documented that the objective of promulgating statutes to regulate financial reporting was to enhance corporate accountability of companies and to provide a roadmap to their formation and operations. The Joint Stock Companies Act was promulgated in 1844 in the UK. He said that this Act, which has been re-enacted severally provided impetus to the promulgation of the Nigeria Companies' Act of 1968 which was amended in 1990 and then 2004. Legal frameworks such as Companies and Allied Matters Act (CAMA), Securities and Exchange Commission (SEC), Central Bank of Nigeria (CBN) and Nigeria Deposits Insurance Commission (NDIC) Act seek to promote corporate accountability (Asada, 2010), provide adequate information for user's decision making, protect users from corporate managerial deception and fraud and ensure healthy competition among corporations. According to the author laws such as SEC, CAMA by regulating corporate financial disclosure serve the purposes of securing capital and protecting the integrity of company capital.

Alturki (2014) Investigated Voluntary disclosure by Saudi Companies, The findings indicated that firms on average report 0.29 of the voluntary information, further in an effort to examine relationship between disclosure level and firms specific characteristics the result of the regression indicated that corporation size, profitability and listed age have significant positive association with voluntary disclosure level in annual report, however, auditor size and leverage do not have an significant association with voluntary disclosure.

Ebrahim and Fattah (2015) examined corporate governance and initial compliance with IFRS in emerging markets on "the case of income tax accounting in Egypt". The results showed corporate governance factors that indicated the sophistication level of both company's management and owners (i.e. institutional ownership and foreign representation on the board), and the perceived quality of the engaged auditor to improve compliance with IFRS requirements. Companies with higher levels of institutional ownership and foreign representation on the board are more likely to engage an audit firm with international affiliation and comply with IFRS recognition and disclosure requirements. From the empirical review, it is clear that some of the studies have inconsistent findings while others ignore the application of intercoder reliability content analysis in assessing voluntary disclosure. This creates a severe gap in literature hence the need to carry out the present study to fill the gap using intercoder reliability content analysis with all the constructs established in the literature. 


\section{THEORETICAL FRAMEWORK}

The theoretical framework of this study focused on the impact of information disclosure on the compliance of telecommunication in Nigeria. The dependent variable is compliance measured on interval scale ranging from 1 to 5 while the independent variable is information disclosure proxy by mandatory information disclosure and voluntary information disclosure measured on a five-point Likert scale.

The underpinning theory for the study is compliance theory, which provides credible evidence of the variables under study. The theory concerns with the question of behavioural motivations about compliance with laws. This is because Telecommunication Companies in Nigeria also expected to comply with the laws and where they fail to comply; there are penalties and sanctions against them. The theoretical framework for this study is reflected in Figure 1, which is based on the extant literature reviewed and the problem statement.

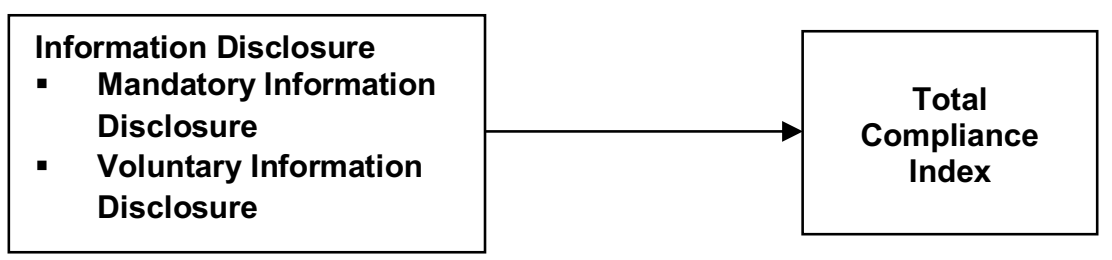

Figure 1: Theoretical Framework

\section{METHODOLOGY}

This study examined the impact of information disclosure on the compliance of telecommunication companies in Nigeria. The study adopted ex-post facto research, this is because the secondary source of data was used. The secondary data was obtained principally from annual reports and account of the selected Telecommunication Companies in Nigeria. This study considered the period 2004 to 2015; this involves an empirical analysis of annual financial report and accounts of the telecommunication companies. The population for the study consists of all the (8) eight telecommunication companies in Nigeria as at December, 31st 2015. Out of this three (3) was selected as a sample which includes, Airtel Nigeria Limited, MTN Nigeria and Globacom. This is due to the size and spread of the network of the selected companies and availability of data. Therefore a scale of 1 to 5 for compliance was developed for both mandatory and voluntary information disclosure, whereby five (5) is assigned for full compliance and one (1) for non-compliance. The qualitative grading system and multivariate regression model were used for data analysis as represented in Table 1.

Table 1. Grading System for the Measurement of Compliance level in Percentage

\begin{tabular}{cccl}
\hline S/NO & Scale & Percentage Score (\%) & Remarks/ Decision Rule \\
\hline 1 & 1 & $01----20$ & Non-Compliance \\
2 & 2 & $21---40$ & Sketching Compliance \\
3 & 3 & $41----60$ & Fair Compliance \\
4 & 4 & $61----80$ & Partial Compliance \\
5 & 5 & $81---100$ & Full Compliance \\
\hline
\end{tabular}

Source: Adapted from Adamu (2015) 
The multivariate regression is specified by the model.

Compliance $=$ Bo

(1) CLit $=\beta 0+\beta 1$ MIDit $+\beta 2$ VIDit $+\varepsilon$ it

Where:

CLit= Compliance,

MIDit= Mandatory Information Disclosure,

VIDit=Voluntary Information Disclosure

$\varepsilon i t=$ Error term. $\beta \_0=$ Regression Intercept, $=\beta \_(1 ;) \beta \_(2)$ parameters to be estimated,

A Priori expectation; $\beta \_1>0$ - implying that MID is influenced by $C L, \beta \_2>0$ - implying that VID is influenced by CL, Where; $\beta \_(1 ;) \beta \_(2)>0$

In order to guarantee the use of content analysis in this study, three master students were used as coders to analyze and code the annual reports and accounts of three samples out of the total population used in this study. Table 2 shows the result of the coding, and the intercoder reliability test using Holsti's (1969) formula.

Table 2. Intercoder Reliability Test Result

\begin{tabular}{lcccc}
\hline \multicolumn{1}{c}{ Unit } & Coder $\mathbf{1}$ & Coder $\mathbf{2}$ & Coder $\mathbf{3}$ & Agreement/Disagreement \\
\hline MTN1 & 1 & 1 & 1 & $\mathrm{~A}$ \\
MTN2 & 1 & 1 & 1 & $\mathrm{~A}$ \\
MTN3 & 0 & 1 & 0 & $\mathrm{D}$ \\
MTN4 & 1 & 1 & 1 & $\mathrm{~A}$ \\
MTN5 & 1 & 0 & 1 & $\mathrm{~A}$ \\
GLO1 & 0 & 0 & 0 & $\mathrm{~A}$ \\
GLO2 & 1 & 1 & 1 & $\mathrm{~A}$ \\
GLO3 & 1 & 1 & 1 & $\mathrm{D}$ \\
GLO4 & 0 & 0 & 0 & $\mathrm{~A}$ \\
GLO5 & 1 & 1 & 1 & $\mathrm{~A}$ \\
A/TEL1 & 1 & 1 & 1 & $\mathrm{~A}$ \\
A/TEL2 & 0 & 0 & 0 & $\mathrm{~A}$ \\
A/TEL3 & 1 & 1 & 1 & $\mathrm{~A}$ \\
A/TEL4 & 1 & 1 & 1 & $\mathrm{~A}$ \\
A/TEL5 & 1 & 1 & 1 & $\mathrm{~A}=11 \times 4=44 ; \mathrm{D}=4 \times 4=16$ \\
15 & $\mathrm{A}=11, \mathrm{D}=4$ & $\mathrm{~A}=11, \mathrm{D}=4$ & $\mathrm{~A}=11, \mathrm{D}=4$ & \\
\hline
\end{tabular}

Based on the result obtained $(73 \%)$ established that the study is deemed to continue with content analysis because $73 \%$ has reached the threshold for reliability test as suggested by Holsti (1969).

\section{RESULTS}

Table 3 shows the level of compliance Computed from Annual Report and Account of the three selected Telecommunication companies (2004-2015). The table shows that MTN is the first in compliance; it had a mean compliance index of 78.3 percent, a maximum of 90 percent, and a minimum of 60 percent and a standard deviation of 9.19 (implying that there was a slight variation in the level of compliance on the profitability of Telecommunication companies. MTN Level of compliance is at partially complied category during the period of the study. This is followed by Airtel, which is second in compliance with relevant provisions of laws, and it has a mean compliance index of 77 percent. With a maximum of 90 percent, a minimum of 60 percent and a standard deviation of 10.59 percent, there is evidence that Airtel partially complies with the provisions of company laws. 
Consequently, Glo came third in regulatory compliance. It had it mean compliance index of 71 percent is under the partial compliance category, maximum of 90 percent, minimum of 60 percent and a standard deviation of 11.97. On the overall average level of compliance with the selected telecommunication companies is 75.6 percent (i,e., partial compliance category).

Table 3. The Level of Compliance

\begin{tabular}{lcccc}
\hline Year & Airtel & MTN & Glo & Mean Compliance Index \\
\hline 2004 & 80 & 70 & 60 & 70 \\
2005 & 60 & 70 & 60 & 63.3 \\
2006 & 80 & 90 & 60 & 76.7 \\
2007 & 90 & 90 & 60 & 70 \\
2008 & 80 & 70 & 60 & 83.3 \\
2009 & 80 & 90 & 80 & 66.7 \\
2010 & 60 & 80 & 60 & 76.7 \\
2011 & 70 & 80 & 80 & 83.3 \\
2012 & 90 & 90 & 80 & 83.3 \\
2013 & 80 & 90 & 90 & 76.7 \\
2014 & 80 & 60 & 90 & 75.6 \\
2015 & 90 & 60 & 70 & \\
Mean Compliance Index & 77 & 78.3 & 71 & \\
Max & 90 & 90 & 90 & \\
Min & 60 & 60 & 60 & \\
Std.Dev. & 10.59 & 9.19 & 11.97 & \\
Rank & 2 nd & 1 st & $3^{\text {rd }}$ & \\
Remark & Partially & Partially & Partially & \\
& Complied & Complied & Complied & \\
Source: Annual Report and Account of the three selected Telecommunication companies (2004-2015).
\end{tabular}

Source: Annual Report and Account of the three selected Telecommunication companies (2004-2015).

Table 4 and Table 5 showed the summary multiple regression results between the dependent variable, total compliance and independent variables, Mandatory information disclosure and voluntary information disclosure. The Mandatory disclosure shows weak relationship at $10 \%$ level of significance while Voluntary disclosure shows partial compliance at $5 \%$ level of significance. This implies that VID has a stronger relationship with Regulatory compliance than MID. The model summary shows that there is a weak correlation between the variables as indicated by the R2 (0.2004) of MID which explains only about $20 \%$ of the dependent variable. This implies that the relationship is weak; however, the voluntary information disclosure explained about $46 \%$ variation in the dependent variable, which signifies partial relationship.

Table 4. Results from the Regression on Mandatory Disclosure

\begin{tabular}{ll}
\hline Variable & Model \\
\hline AMID & $0.996^{*}$ \\
& $(1.990)$ \\
Cons & $4.899^{* \star}$ \\
& $(3.030)$ \\
Number of obs & 40 \\
F( 2, 37) & 4.64 \\
Prob > F & 0.016 \\
R-squared & 0.2004 \\
Adj R-squared & 0.1572 \\
Root MSE & 1.2279 \\
\hline
\end{tabular}

Note: ${ }^{* * *}$ significant at $1 \%,{ }^{* *}$ significant at $5 \%$ and ${ }^{*}$ significant at $10 \%$;

Coefficients and figures in apprentices are t-values. 
Table 5. Result from the Regression on Voluntary Disclosure

\begin{tabular}{ll}
\hline Variable & Model \\
\hline AVID & $0.391^{* *}$ \\
& $(1.86)$ \\
Cons & $.370^{* *}$ \\
& $(2.51)$ \\
Number of obs & 40 \\
F( 4, 31 & 6.52 \\
Prob > F & 0.0006 \\
R-squared & 0.4569 \\
Adj R-squared & 0.3868 \\
Root MSE & 1.0329 \\
\hline Note: ${ }^{* * *}$ significant at $1 \%,{ }^{* *}$ significant at $5 \%$ and ${ }^{*}$ significant at $10 \%$. & \\
Coefficients and figures in apprentices are T-values. & \\
Source: Stata Output. &
\end{tabular}

The F-Statistics of 4.64 and corresponding significant (probability) value of 0.016 shows that the independent variable jointly explains or influences the dependent variables. The coefficient of the individual variables shows that MID is significant at (0.996) and VID has Coefficient of 0.3910 and probability of 0.0006 . However, Voluntary information disclosure has more influence on compliance than the Mandatory information disclosure since it significantly at $5 \%$. The combined impact of the independent variables explained $46 \%$ variation in the dependent variable. This implies that the lower the levels of mandatory and voluntary disclosure, the lower the Telecommunication comply with the regulatory requirements. This finding is consistent with the findings of Cooke (1992) which revealed that mean scores for mandatory disclosure are lower. A linear regression model was used to test the hypothesis. This, therefore, supports hypothesis one. On the other hand, the VID is significant at $5 \%$, which support the hypothesis because the expected outcome is positive. This finding shows that the higher the level of voluntary disclosure the higher the regulatory compliance.

\section{DISCUSSION OF FINDINGS AND IMPLICATION}

The findings of the multiple regression results show that Telecommunication Companies in Nigeria partially complied with the legal requirement of the laws of the country by sufficiently to have partial disclosed the required information. Abubakar (2010) suggested that the responsibility of setting- up regulatory agencies by the government to issue and ensure compliance with standards and guidelines rest on the affected companies. Furthermore, The study also reveals that mandatory information disclosure significant impact at $10 \%$. This shows weak compliance by the telecommunication companies which is significance concurred with the study of Ishaq (2013) on Corporate Governance and Financial Reporting Quality in the Nigerian Oil Marketing Industry

\section{CONCLUSION AND RECOMMENDATION}

It is concluded that the level of compliance with existing regulation required was partial which showed some internal weaknesses and consequent distress on the operations of the telecommunication companies in Nigeria. To this effect, there is a clarion call for the enforcement of full compliance by all the Telecommunication companies in Nigeria. It is therefore recommended that NCC should monitor the compliance with the requirements of information disclosure and pursue its objective to achieve best corporate governance practices in Nigerian telecommunication companies. 


\section{REFERENCES}

Abubakar, S. (2010). Regulation and the economics of corporate financial reporting in Nigeria. Journal of Management and Enterprises Development, 7(2), 65-72.

Alturki, K. H. (2014). Islamic Banks versus Commercial Banks and Performance: The Context of Saudi Arabia?. Global Journal of Management And Business Research.

Asada, D. (2010). Statutory controls for financial accounting practices in Nigeria. Retrieved from http:///dspace.unijos.edu.ng/bitstream/123456789/0485/1/statutory\%20control\%20for\%20fi nancial\%20accounting\%20practice\%20Nigeria.pdf

Barde, L. M. (2009). Nigeria oil marketing companies and compliance with the requirement of Statement of accounting standards (SAS). In Dandago, K. I. (Eds) Contemporary Issues in Accounting, auditing and taxation (104-125) Kano Triumph Publishing Company Limited.

Bleck, A., \& Liu, X. (2007). Market transparency and the accounting regime. Journal of Accounting Research, 45(2), 229-256.

Central Bank of Nigeria, (2009), Annual reports and statement of Accounts (2009) - coded of corporate governance for banks in Nigeria post consolidated Abuja.

Chamisa, E. E. (2000). The relevance and observance of the IASC standards in developing countries and the particular case of Zimbabwe. The International Journal of Accounting, 35(2), 267-286.

Cohen, S. (1985). Visions of social control: Crime, punishment and classification (pp. 127-143). Cambridge: Polity Press.

Cooke, P. (1992). Regional innovation systems: competitive regulation in the new Europe. Geoforum, 23(3), 365-382.

Cowan, S. \& Gadenne, D. (2005). Australian corporate environmental reporting; A Comparative Analysis of Disclosure Practices across Voluntary and Mandatory disclosure system. Journal of Accounting \& Organizational Change. 1(2), 166-179.

Ebrahim, A., \& Fattah, T. A. (2015). Corporate governance and initial compliance with IFRS in emerging markets: The case of income tax accounting in Egypt. Journal of International Accounting, Auditing and Taxation, 24, 46-60.

Holsti, O. R. (1969). Content analysis for the social sciences and humanities. Addison-Wesley Pub. Co.

Ishaq, A. S. (2013). Corporate Governance and Financial Reporting Quality in the Nigerian Oil Marketing Industry.

Kantudu, A. S., \& Tanko, M. (2008). Compliance with the requirements of accounting standards by quoted companies in Nigeria. Retrieved from https://ssrn.com/abstract $=1150973$ or http://dx.doi.org/10.2139/ssrn.1150973

Kaufmann, D. (1997). Corruption the facts; Foreign Policy, Sauemmer.

Meek, G. K., Roberts, C. B., \& Gray, S. J. (1995). Factors influencing voluntary annual report disclosures by US, UK and continental European multinational corporations. Journal of international business studies, 26(3), 555-572.

Owusu-Ansah, S. (1998). The impact of corporate attribites on the extent of mandatory disclosure and reporting by listed companies in Zimbabwe. The International Journal of Accounting, 33(5), 605-631.

Paul, M. (2015). 37 CFR 1.97 Filling of information disclosure (R.07. 2015)

Tom, C. W. L. (2016). Compliance Technology and Modern Finance, Journal of Corporate, Financial \& Commercial Law, 11, 159. 